\title{
The Immunolocalization of Cadherins and Beta- Catenin in the Cervix and Vagina of Cycling Cows
}

Narin Liman ( $\square$ narinliman@gmail.com )

Erciyes University: Erciyes Universitesi https://orcid.org/0000-0001-5489-2719

\section{Hakan Sağsöz}

Dicle University: Dicle Universitesi

\section{Research Article}

Keywords: Beta-catenin, Bovine, Cadherin, Cervix, Vagina

Posted Date: April 16th, 2021

DOl: https://doi.org/10.21203/rs.3.rs-421020/v1

License: (9) This work is licensed under a Creative Commons Attribution 4.0 International License. Read Full License 


\section{Abstract}

The adherens junction (AJ) maintains the structural integrity and barrier function of the epithelial cell layers. AJs also play a key role in a variety of biological and pathological processes, from morphogenesis to tumor progression. AJs perform these functions through the cadherin-catenin adhesion complex. In this study, we investigated the presence, cell-specific localization, and temporal distribution of AJ components such as cadherins and beta-catenin in the cow cervix and vagina during the oestrous cycle using immunohistochemistry. The cow genitalia $(n=30)$ were collected from an abattoir and the cervix and vagina were categorized into the follicular and luteal groups based on cyclicity. Results demonstrated constitutive expression of beta-catenin and placental $(P)$ - and epithelial $(E)$-cadherins, but not neural $(\mathrm{N})$-cadherin, in ciliated and non-ciliated columnar cervical cells, the luminal, parabasal, intermediate, and basal layers of the stratified vaginal epithelium of the bovine cervix and vagina throughout the oestrous cycle. The honeycomb-like membrane staining pattern for selected junctional molecules was observed in the epithelial cells. While there were no noticeable variations in the immunostaining intensity of P-and E-cadherin and beta-catenin proteins in the cervical and vaginal epithelium between the oestrous phases, the immunolocalization patterns altered by structural changes that occurred in response to oestrogen and progesterone hormone levels during the oestrous cycle. These results may indicate that $\mathrm{P}$ - and $\mathrm{E}$-cadherin and beta-catenin participate in maintaining the integrity and barrier function of the cervical and vaginal epithelium throughout the oestrous cycle, thus helping to maintain the sterility of the uterine cavity.

\section{Introduction}

The reproductive tract of cows is equipped with anatomical and physical barriers that prevent the entry and colonization of many bacteria, and tissue damage. The anatomical barriers include the vulvar sealing, vestibule-vaginal constriction, the cervix, cervicovaginal mucus secretion (Sheldon et al. 2014; Dadarwal et al. 2017). The epithelium lining the cow genital tubular organs serves as an effective primary physical barrier against most microorganisms. The type and thickness of the epithelium are different in these organs. The vagina serves as the receptacle for the male penis during copulation and it is the site of semen deposition during natural mating. It is covered with a stratified epithelium that secretes fluids that combine with cervical fluids to inhibit the growth of undesirable bacteria. Therefore, vaginal epithelium constitutes the first line of defence against invading pathogens either faecal or environmental origin. The cervix is a passageway for sperm during mating and for the fetus during delivery. The main function of the cervix is to isolate the uterus from the external environment. Extensive foldings of the cervical mucosa are important physical barriers that prevent microbial entry into the uterus. (Mullins and Saacke 1989; Dadarwal et al. 2017). In contrast to the vestibule and vagina, the cervical mucosa is lined a simple columnar epithelium similar to the uterus and oviduct. The cervical epithelium produces mucus, which lubricates the vagina for copulation and serves as a suitable environment for sperm survival, and protects the cervical stroma and upper reproductive tract against the invasion of microbes entering through the vagina (Mullins and Saacke 1989; Tsiligianni et al. 2011). 
Like other parts of the female reproductive tract, the cervix and vagina undergo extensive organ-specific morphological changes in association with the circulating levels of oestrogen (E2) and progesterone (P4) in cycling animals. In the cow cervix and vagina, cyclical variations in circulating concentrations of E2 and $\mathrm{P} 4$ regulate several physiological processes, such as epithelial proliferation, the production and rheological properties of cervical mucus (Pessina et al. 2006; Larsen and Hwang 2011; Tsiligianni et al. 2011), and vaginal pH and secretion viscosity (Rizvi et al. 2009). Throughout pregnancy, progesterone promotes the production of highly viscous mucus resulting in the formation of a plug that temporarily seals the cervix so that pathogens do not harm the fetus. When these epithelial barriers in the cervix and vagina are broken by microorganisms, the reproductive tract becomes contaminated and inflamed (Sheldon et al. 2014; De Tomasi et al. 2019). For example, after parturition, the reproductive tract is opened due to the dilated state of the cervix and also inflamed. The latter allow pathogens to ascend from the external environment or through blood into the uterine lumen, which if persisting, can cause clinical diseases that might lead to subfertility and/or infertility (Sheldon et al. 2014). Therefore, epithelial integrity may be important for maintaining of the vaginal and cervical epithelial barrier function and protecting of the sterility of the uterine cavity.

The integrity and barrier function of epithelial layers are regulated by specialized cellular structures consisting of multiprotein complexes known as intercellular junctions. These structures, which are classified into three main types, namely, tight junctions (zonula occludens, TJs), adherens junctions (zonula adherens, AJs), and gap junctions (GJs), maintain epithelial organization and integrity throughout life by regulating molecular and cellular traffic and providing a physical barrier to pathogen invasion (Blaskewicz et al. 2011). TJ and AJ provide important adhesive contacts between neighboring epithelial cells. The disruption of them causes the loosening of cell-cell contacts, leading to disorganization of tissue architecture. The core components of AJs are clusters of cadherin molecules and a group of intracellular anchor proteins, referred to as catenins (Gumbiner 2005).

Cadherins, a superfamily of transmembrane glycoproteins, are divided into subfamilies, including classical, desmosomal, proto-, and atypical cadherins (Harris and Tepass 2010). Classical cadherins were originally identified as $\mathrm{Ca}^{2+}$-dependent, homophilic adhesion molecules in vertebrates. Based on phylogenetic relationships, classical cadherins are subdivided into two families, namely, type I [epithelial $(\mathrm{E})$-, placental (P)-, neural (N)-, and retinal (R)- cadherins] and type II (vascular endothelial (VE)-, kidney (K)-, and osteoblast (OB)-cadherins) (Nollet et al. 2000).

Classical and desmosomal cadherins feature an amino-terminal extracellular region (ectodomain) composed of five extracellular cadherin (EC) repeats and a carboxy-terminal intracellular region (cytoplasmic domain). Interactions between the ectodomains of classical cadherins on opposed cells mediate specific cell-cell contacts, whereas the cadherin cytoplasmic domain functionally links to cytoskeletal actin filaments through catenins (alpha (a)-, beta ( $\beta$ )-, and gamma ( $\mathrm{\gamma}$ )-catenin). The cadherin cytoplasmic domain establishes a high affinity, 1:1 complex with beta-catenin, and beta-catenin binds to a-catenin with a lower affinity (Huber and Weis 2001). These molecular components of AJ are responsible primarily for tissue-specific cell-cell adhesion (Nelson 2008) and play a key role in a variety of 
biological and pathological processes, from morphogenesis to tumor progression (Hazan et al. 2004; Gumbiner 2005; Halbleib and Nelson 2006; Jeanes et al. 2008; Harris and Tepass 2010; Jiang et al. 2019). Also, the protein beta-catenin is an important mediator of the canonical Wnt/beta-catenin signalling pathway (Nelson and Nusse 2004).

Cadherins are one of the adhesion molecules associated with reproduction (Rowlands et al.2000). A review of available data indicates that, in female reproductive tissues such as uterus and ovary, classical cadherins (van der Linden et al. 1994; 1995; Fujimoto et al. 1996; Machell et al. 2000; Poncelet et al. 2002; Shih et al. 2004; Jha et al. 2006; Yue at al. 2009; Guo et al. 2010; Kiewisz et al. 2011; Luan et al. 2011; Caballero et al. 2014; Payan-Carreira et al. 2016; Tienthai 2018) and beta-catenin (Jeong et al. 2009; Jha et al. 2006; Li et al. 2005; Luan et al. 2011; Mohamed et al. 2005; Shih et al. 2004) are necessary for epithelial continuity, folliculogenesis, maintenance of endometrial architecture, endometrial receptivity to blastocyst implantation, and tissue remodelling processes during the oestrous cycle. Furthermore, Wnt/beta-catenin signalling is also important for the regulation of endometrial proliferation and differentiation (Tulac et al. 2003; van der Horst et al. 2012). While many studies have been published on cadherin and beta-catenin expression in the epithelia of the upper reproductive tract organs of various mammalian species, including humans (Inoue et al. 1992; Fujimoto et al. 1996, Shih et al. 2004; Tsuchiya et al. 2006), mice (Maccalman et al. 1994; Potter et al. 1994), monkeys (Allan et al. 2003), pigs (Ryan et al. 2001; Kiewisz et al. 2011), dogs (Yue et al. 2009; Guo et al. 2010; Payan-Carreira et al. 2016), and cattle (Caballero et al. 2014; Tienthai 2018) during pregnancy and the oestrus cycle, to date, only very few studies have addressed cadherin and beta-catenin expression by normal cervical and vaginal epithelial cells (Inoue et al. 1992; Blaskewicz et al. 2011; Crasta et al. 2016). Previous studies have also shown that E2 and P4 regulate beta-catenin (Chen et al. 1998; Rider et al. 2006) and cadherin expression (Guo et al. 2010; Ryan et al. 2001; Kiewisz et al. 2011; Yue et al. 2009) in uterine endometrial cells.

Cervical cancer is the fourth most common malignant tumor in women worldwide with high morbidity and mortality (Arbyn et al. 2020). Because most cervical tumors of humans are of epithelial origin (Doorbar and Griffin 2019) and any disturbances in cell-cell and cell-matrix adhesion are related to tumor progression (Jiang et al. 2019), adhesion molecules at the junctions of epithelial cells are of great interest. Therefore, most studies on the expression of cadherin and beta-catenin in the cervical tissue have focused on cervical carcinomas of the human endo- and ectocervix (Inoue et al. 1992; Vessey et al. 1995; de Boer et al. 1999; Han et al. 2000; Carico et al. 2001; Felix et al. 2002; Fadare et al. 2005; RodríguezSastre et al. 2005; Auvinen et al. 2013; Crasta et al. 2016). To our knowledge, there is currently no comparative study on the expression of cadherins and beta-catenin by columnar epithelial cells of the cervix versus stratified squamous epithelial cells of the vagina in cycling cows. Furthermore, there is no data available on the impact of the hormonal status of bovine animals during the oestrus cycle on cadherin and catenin expression in the cervix and vagina. It is therefore necessary to investigate whether immunolocalization of $\mathrm{E}-, \mathrm{P}-$, and $\mathrm{N}$-cadherins and $\beta$-catenin is altered in normal cervix and vagina of the cycling cows. 
Therefore, this study intends: (1) to confirm the presence and the immunolocalization of classical E-, P-, and $\mathrm{N}$-cadherins and beta-catenin in the bovine cervix and vagina; (2) to determine the temporal and spatial effects of E2 and P4 levels on tissue- and cell-specific changes in the distribution of cadherins and beta-catenin in the cow cervix and vagina during the oestrous cycle.

\section{Materials And Methods}

\section{Animals ethics statement and experimental conditions}

In our study, tissue samples of animals were taken in accordance with the rules of the Regulation on the Working Procedures and Principles of Animal Experiments Ethics Committees of the Ministry of Forestry and Water Affairs (dated 15 February 2014, 28914). This regulation has been prepared on the basis of Animals Protection Law (dated 24 April 2004, 51999) published by Official Gazette dated 1 July 2004 and in accordance with the Universal Declaration of Animal Rights, the European Convention on the Protection of Vertebrate Animals for Experimental and Other Scientific Purposes (Council of Europe ETS 123), and Guide for the Care and Use of Laboratory Animals. In this regulation, it has been reported that the permission of Animal Experiments Local Ethics Committee' is not required in some cases including the clinical applications for diagnosis and treatment purposes, in procedures with dead animals or their tissues, slaughterhouse materials, aborted fetuses, milk samples, fecal or litter sample collection, and swab sampling, etc. Slaughter of animals in slaughterhouses is carried out under the control of veterinarians following the hygiene rules, at once without frightening, with the least pain. In slaughterhouses, blood drawing process can be done easily with the open draining method. In this method, when the butcher cuts the throat of the animal, the flowing blood is taken directly into the tube with a funnel. For the reasons explained above, no ethics committee approval was obtained before starting our study.

In this study, a total of 30 healthy Holstein cows aged 2-8 years, which were obtained from local abattoirs in Diyarbakır Province, Turkey, were used. Before slaughter, cows were checked for evidence of oestrous behaviors, including mounting or attempting to other cattle, smelling and trailing of other females, vulvar swelling and reddening, clear vaginal mucus discharge, and mucus smeared on the rump (Peralta et al 2005), before they were killed. After the cows had been killed, the entire reproductive tract was removed and macroscopically examined for the presence of disease. Animals without any clinical sign such as purulent uterine discharge, necrotic or hemorrhagic uterine mucosa, cervical or vaginal hyperemia, and edema, malodorous or non-odorous, purulent or mucopurulent vaginal discharge (Millward et al 2019) were included in this study.

\section{Collection of blood samples and measurement of hormone concentrations}

To measure serum concentrations of E2 and P4 hormones, the bloods of pre-selected cows were taken into a tube as soon as their throat was cut by the butcher and then, transported to the laboratory immediately after collection. After arriving at the laboratory, the samples were centrifuged $(3969 \mathrm{~g}$ for 5 min at $4{ }^{\circ} \mathrm{C}$ ). All serum samples were stored at $-20^{\circ} \mathrm{C}$ until analysis. Serum concentrations of E2 and P4 
were measured in a clinical laboratory (PRO-LABORATORY Laboratory Technologies, Istanbul) by enzyme immunoassay (EIA) using commercially available kits (DRG Aurica Elisa Oestradiol Kit (Catalogue no. EIA-2693) and DRG Aurica Elisa Progesterone Kit (Catalogue no. EIA-1561) respectively; DRG International) according to the manufacturer's protocol.

\section{Collection of tissue samples and histological analysis}

After the macroscopic examination of the entire genital tract of the killed cows, small pieces about $2 \mathrm{~cm}$ in size depending on the organ were cut out from the ovaries (right and left), uterine horns (right and left), cervix, and vagina, and were immersed in $10 \%$ buffered formalin. In the bovine cervix, the cervical mucosa forms three to four annular folds or rings that project into the lumen, as well as numerous smaller longitudinal folds (Breeveld-Dwarkasing 2002). Therefore, the tissue samples used in this study were harvested from all three rings of the cervix, and from the vaginal area adjacent to the vulva. After fixation process, all tissue samples washed in tap water, dehydrated through an ethanol series $(70 \%, 80 \%, 96 \%$, $100 \%$ ) and embedded in paraffin. To evaluate the histological changes that occur in the ovary and uterus during the oestrous cycle, the paraffin-embedded tissue samples of the right and left ovaries and the uterine horns of each animal were cut on a microtome into $7 \mu$ m-thick sections, and these slides were stained with a modified Mallory's connective tissue stain (Crossmon 1937). Furthermore, for the histological evaluation of the cervical and vaginal epithelia, the paraffin-embedded cervical and vaginal tissue samples of each animal were cut at the $5-\mu \mathrm{m}$ thickness, and slides were prepared and stained for mucin with Periodic acid-Schiff (PAS), in view of the bovine cervical and vaginal epithelia containing high levels of carbohydrates, including mucins, during the follicular stage of the oestrous cycle (Wrobel 1971; Wrobel et al 1986; Mullins and Saacke 1989; Miroud and Noakes 1991).

\section{Determination of oestrous cycle phase}

The phase of the cycle in the slaughtered cows was determined postmortem. The phase of the oestrous cycle of each cow was determined based on the presence/absence of corpora lutea (CL) or preovulatory follicles in the ovaries, the histological findings detected in the ovaries and uterus, and E2 and P4 concentrations measured in the serum samples (Benbia et al. 2017). The presence of a preovulatory follicle and fully developed CL were assumed as the characteristic features of the follicular and luteal phases of the oestrous cycle, respectively. The mean ( \pm s.d.) serum E2 concentration was higher during the follicular phase $\left(28.55 \pm 9.36 \mathrm{pg} / \mathrm{mL}^{-1}\right.$ ) (ranging from 16.20 to $58.30 \mathrm{pg} / \mathrm{mL}^{-1}$; Benbia et al. 2017) compared to the luteal phase $\left(10.73 \pm 4.06 \mathrm{pg} / \mathrm{mL}^{-1}\right)$ (range $3.50-13.20 \mathrm{pg} / \mathrm{mL}^{-1}$; Benbia et al. 2017), whereas the mean ( \pm s.d.) P4 concentration was higher during the luteal phase $\left(6.31 \pm 0.98 \mathrm{ng} / \mathrm{mL}^{-1}\right)$ (range $4.00-8.20 \mathrm{ng} / \mathrm{mL}^{-1}$; Benbia et al. 2017) compared to the follicular phase $\left(0.91 \pm 0.33 \mathrm{ng} / \mathrm{mL}^{-1}\right.$ ) (ranging from 0.40 to $1.30 \mathrm{ng} / \mathrm{mL}^{-1}$; Benbia et al. 2017). Based on these data and literature information (Benbia et al. 2017; Crowe 2016), the cows were divided into two groups, including a follicular phase group $(n=13)$ and a luteal phase group $(n=17)$. Similar to other domestic animals the oestrus cycle in the cow can be divided into four phases: proestrus, oestrus, metoestrus, and dioestrus. Proestrus and oestrus 
comprise the follicular phase of the ovarian cycle with ovulation taking place 10 to 12 hours after the end of oestrus. Metoestrus and dioestrus constitute the luteal phase of the cycle (Crowe 2016).

\section{Immunohistochemistry}

A standard strepavidin-biotin immunoperoxidase technique (Thermo Fisher Scientific Lab Vision Corporation, Fremont) was applied to detect the $\beta$-catenin and cadherin proteins. Briefly, the $5-\mu m$ paraffin-embedded cervical and vaginal sections were deparaffinised and treated with $3 \%$ hydrogen peroxide $\left(\mathrm{H}_{2} \mathrm{O}_{2}\right)$ in methanol for $15 \mathrm{~min}$ to block endogenous peroxidase activity. After rinsing thoroughly in phosphate buffer saline (PBS) ( $\mathrm{pH} 7.4)$, the sections were placed in $0.01 \mathrm{M}$ citrate buffer $(\mathrm{pH} 6.0)$, heated in a water bath at $80^{\circ} \mathrm{C}$ for 30 minutes for antigen retrieval, and cooled for $20 \mathrm{~min}$. Then, the sections were washed in PBS and treated with a blocking solution (Ultra V Block, Thermo Fisher Scientific, LabVision Corporation, Fremont, CA) for 5 min to prevent nonspecific interference of immunoglobulins. Subsequently, the sections were incubated at $4{ }^{\circ} \mathrm{C}$ overnight with the following antibodies: anti-pancadherin (Ab-4) [RB-1524, Thermo Fisher Scientific Lab Vision Corporation, Fremont, CA, USA, 1:200 dilution], anti-E-cadherin [ab15148, Abcam, 1:50 dilution], anti-P-cadherin [ab-137729, Abcam, 1:200 dilution], anti-N-cadherin [clone 13A9, sc-59987, Santa Cruz Biotechnology, Santa Cruz, CA, USA, 1:100 dilution], and anti-beta-catenin (E-5) [clone E-5, sc-7963, Santa Cruz Biotechnology, Santa Cruz, CA, USA, 1:100 dilution]. Next, the sections were incubated with the secondary antibody and streptavidin peroxidase (Thermo Fisher Scientific Lab Vision Corporation, Fremont, CA), followed by incubation with diaminobenzidine (DAB) substrate for $5 \mathrm{~min}$. Subsequently, the sections were counterstained with Gill's haematoxylin for 3 min, washed under running tap water, dehydrated through an alcohol series, cleared in xylene and mounted in Entellan (Merck).

As it is known, beta-catenin and cadherin antibodies specific for bovine tissues are not yet commercially available or their commercial production is limited. In the product datasheets of Pan-cadherin and Pcadherin antibodies used in this study have been reported to be positive for bovine tissues. Furthermore, various researchers showed that the $\mathrm{N}$-cadherin antibody used in this study was positive for bovine ovaries (Lee et al. 2019) and beta-catenin antibody for Madin-Darby bovine kidney (MDBK) cells (Fay et al. 2020). We could not perform western blot analysis because the tissue samples examined in this study were prepared in paraffin long before and there was no fresh tissue sample in our laboratory. However, we confirmed in another study that $\mathrm{E}, \mathrm{P}$ and $\mathrm{N}$-cadherin proteins are expressed in tissue lysates of bovine placenta (unpublished data). Therefore, to determine the distribution of beta-catenin and type I classical cadherins i.e. E-, P-, and N-cadherin, we used polyclonal or monoclonal beta-catenin, E-cadherin, $\mathrm{N}$ cadherin, and P-cadherin antibodies developed for use in several mammalian tissues.

Negative and positive controls were used to control the specificity of the immunostaining of the cadherin and beta-catenin proteins. Archived blocks of the bovine uterus, placenta, and abomasum served as positive controls for $\mathrm{E}-, \mathrm{P}-$, and $\mathrm{N}$-cadherin, and beta-catenin. Archived paraffin blocks of the bovine ovary and liver were also stained for N-cadherin. Normal rabbit IgG (Santa Cruz sc-2027) instead of pancadherin, and E- and P-cadherin and normal mouse IgG (Santa Cruz Sc-2025) instead of anti-N-cadherin 
and anti-beta-catenin antibodies were used as negative controls. No specific immunostaining was detected in the negative control sections of the cervix and vagina when a normal rabbit or mouse IgG was used instead of primary antibodies (Fig. 2A-D). Whereas, the positive control tissues were immunopositive for cadherins and $\beta$-catenin (Fig. 2E-H). These results indicate that the commercial antibodies employed in the present study were suitable for use in bovine tissues.

\section{The semi-quantitative evaluation of immunostainings}

Immunostainings for E-, P-, N-cadherin and beta-catenin were evaluated semi-quantitatively using a fourpoint intensity score (IS) (Detre et al 1995). Positive immunostaining for all cadherins and beta-catenin were determined in high-expression areas by scanning the cervical and vaginal sections at magnifications of $X 40, X 100, X 200$, and $X 400$. The staining was scored as (-) negative, $(+)$ weak, $(++)$ moderate, or (+++) strong. The subcellular, cellular and tissue localizations of E-, P-, N-cadherin and betacatenin were evaluated independently for three tissue layers (epithelium, stroma and smooth muscle layer) and blood vessels in the cervix and vagina. The serosa was present in only some cervical sections as it was lost during the fixation and embedding procedures and is, therefore, not included in the results. Furthermore, in the present study, the terminology described by Mullins and Saacke (1989) was used to define the location of the epithelial cells in the cervical mucosa. The epithelium was defined according to its location in the central lumen, primary folds, secondary folds, and grooves, Firstly, the epithelium surrounding the cervical lumen and lining the longitudinal primary folds was described as the central region epithelium, while the epithelium covering the secondary folds was called as the peripheral region epithelium. Secondly, the epithelium was defined according to its location in the grooves. While the term "basal area" was used to identify areas, where epithelial cells were within grooves, the term "apical area" described areas, where epithelial cells were situated between grooves. Accordingly, epithelial immunostaining was evaluated in the epithelia of the central canal, primary and secondary folds, and the apical and basal areas of the grooves.

\section{Results}

\section{Mucosal morphology of the cervix and vagina during the oestrous cycle}

The histological evaluation of the cervix, stained with PAS and modified Mallory's connective tissue stain (data not shown), revealed that the mucosa of the cervix was characterized by longitudinal primary folds and secondary folds, which ran obliquely in the lateral walls of the primary folds, and grooves covered all surfaces. The number of secondary folds and grooves was highest during the follicular phase and decreased during the luteal phase.

Histologically, the central and peripheral region epithelia and the epithelium lining grooves contain two distinct cell types; (1) non-ciliated secretory columnar and (2) ciliated secretory columnar epithelial cells. The number of non-ciliated cells in the basal areas of the grooves was greater than that in the apical areas. In the cervix, both epithelial cell height and the number of non-ciliated epithelial cells were greater during the follicular phase, compared to the luteal phase. The ciliated epithelial cells were constricted 
between two adjacent non-ciliated cells during the follicular phase. The later contained a large amount of stored PAS-positive mucins in the apical cytoplasm during the follicular phase of the oestrous cycle (Fig. $1 \mathrm{~A}$ and $\mathrm{B})$. In contrast, during the luteal phase, it was difficult to distinguish between the ciliated and nonciliated cells as the amount of stored PAS-positive mucins had significantly decreased in the non-ciliated epithelial cells (Fig. 1C and D).

In the bovine vaginal mucosa presented numerous deep folds during the follicular phase of the oestrous cycle. The vaginal epithelium was composed of stratified cells. The luminal surface cells of the vaginal epithelium exhibited different morphology depending on the phases of the oestrus cycle. During the follicular phase, the luminal surface of the vaginal epithelium was composed of cuboidal or columnar epithelial cells which contained a large amount of stored PAS-positive mucins (Fig. 1E and F). In contrast, during the luteal phase, the luminal surface cells of the vaginal epithelium were squamous or cuboidal in shape and contained small amounts of stored PAS-positive mucins (Fig. 1G and H).

\section{Immunolocalization of cadherins and beta-catenin in the cervix and vagina during the oestrus cycle}

The immunolocalization patterns of cadherins and beta-catenin in the cervical and vaginal cells are summarized in Table and Figures 3-5. N-cadherin was not expressed in the normal cervical and vaginal tissues of cycling cows.

\section{Cervical epithelium}

The immunolocalization patterns in the cervical epithelia altered with structural changes that occurred in response to E2 and P4 hormone levels during the oestrous cycle, but did not differ among the central and peripheral regions of the cervical epithelium. During both phases of the oestrous cycle, $\mathrm{P}$-, and E-cadherin and beta-catenin exhibited a honeycomb like immunoreaction pattern in the central and peripheral region epithelium of the cervical mucosa. P-cadherin (Fig. 3A-D) displayed strong membranous and cytoplasmic expression patterns in the ciliated cells, and moderate membranous immunolocalization in the nonciliated cells. However, a fairly strong localization of E-cadherin (Fig. 4A-D) and beta-catenin (Fig. 5A-D) was observed in the lateral membrane of both ciliated and non-ciliated cells in the epithelium of the central and peripheral regions. Moreover, weak to moderate immunostaining for E-cadherin and betacatenin was observed in the cytoplasm of the ciliated epithelial cells.

\section{Vaginal epithelium}

We observed that all normal vaginal samples stained positively for $\mathrm{P}$, and E-cadherin and beta-catenin throughout the oestrous cycle (Figs. 3-5). The immunolocalization patterns in the vaginal epithelia altered with structural changes that occurred in response to E2 and P4 hormone levels during the oestrous cycle, but immunostaining intensities were not significantly different between the follicular and luteal phases. During both the follicular and luteal phases, the basal and parabasal cell layers of the epithelium showed moderate cytoplasmic and strong membrane staining for P- and E-cadherin (Figs. 3E-F, and 4E-F, respectively) and beta-catenin (Fig. 5E-F). During the follicular phase, the superficially located, tall, 
columnar, highly active and mucus-secreting cells displayed strong membrane and weak cytoplasmic staining for P- (Fig. 3E) and E-cadherin (Fig. 4E) and beta-catenin (Fig. 5E). During the luteal phase, the superficial squamous cells showed moderate cytoplasmic and sometimes membranous expression of Pcadherin (Fig. 3F). Furthermore, during this phase, strong membrane and moderate cytoplasmic immunostaining for E-cadherin (Fig. 4F) and beta-catenin (Fig. 5F) was observed in the superficial squamous cells. Furthermore, the vaginal epithelial cells also exhibited nuclear immunostaining for Pcadherin throughout the oestrous cycle (Fig. 3E-F)

\section{Stroma and muscle layer of the cervix and vagina}

In the cervical and vaginal stroma, P-cadherin immunoreactivity was detected in the nuclei and cytoplasm of some connective tissue cells (Fig. 3), whereas there was no immunostaining for both E-cadherin and beta-catenin throughout the oestrous cycle (Figs. 4,5). The smooth muscle cells of the cervix and vagina exhibited moderate to strong cytoplasmic and nuclear immunolabelling for P-cadherin (Fig. 3G). However, the immunoreaction for both E-cadherin and beta-catenin was absent in the cervical and vaginal smooth muscle cells (data not shown). In the cervical and vaginal stroma, the endothelial cells of the capillaries and large blood vessels and the vascular smooth muscle cells showed moderate cytoplasmic and strong nuclear expression patterns for P-cadherin (Fig. 3H), but not E-cadherin. Beta-catenin immunoreactivity was only observed in the lateral plasma membrane of endothelial cells of the capillaries and large blood vessels in both cervix and vagina (Fig. 5G).

Generally, immunostaining intensities for all adhesion molecules remained the same in the cervical and vaginal components throughout the oestrous cycle.

\section{Discussion}

In this study, we compared the presence, cell-specific localization and temporal distribution of the cadherin-mediated pathway in intercellular adherens junction in the cow cervix and vagina during the follicular and luteal phases of the oestrous cycle. The results obtained in the present study using immunohistochemistry indicate that while $\mathrm{P}$ - and E-cadherin and beta-catenin are constitutively expressed in a cell type-specific manner, $\mathrm{N}$-cadherin is not expressed in the cow cervix and vagina throughout the oestrous cycle.

The cervix and vagina are composed of complicated, hormone-dependent tissues. These tissues undergo extensive organ-specific structural changes in association with the circulating levels of E2 and P4 in cycling animals. During the oestrous cycle, an $\mathrm{E}_{2}$ surge promotes and a $\mathrm{P}_{4}$ surge inhibits epithelial cell proliferation in the cervix and vagina (Pessina et al. 2006; Larsen and Hwang 2011). In the present study, histological findings showed that follicular phase of the oestrous cycle was characterized by the appearance of the mucification of the epithelium of the cow cervix and vagina. The cow cervix has a highly active secretory epithelium during the follicular phase, in response to rising circulatory titres of $E_{2}$ $\left(28.55 \pm 9.36 \mathrm{pg} / \mathrm{ml}^{-1}\right)$. The amount of non-ciliated epithelial cells during the follicular phase was greater 
than that during the $\mathrm{P} 4\left(6.31 \pm 0.98 \mathrm{ng} / \mathrm{ml}^{-1}\right)$-dominant luteal phase of the oestrous cycle. Therefore, ciliated cells were constricted between two adjacent non-ciliated cells during the follicular phase. In the vagina, the luminal surface cells of the vaginal epithelium were either cuboidal or columnar in shape and contained a large amount of stored PAS-positive mucins during the follicular phase, whereas during the luteal phase, these cells were squamous or cuboidal in shape and contained small amounts of mucins. These findings revealed that the changes in the epithelial morphology of the cow cervix and vagina a result of hormonal status. However, it is worth emphasizing that that there were no noticeable variations in the immunostaining patterns of $\mathrm{P}$ - and E-cadherin and beta-catenin proteins in the cervical and vaginal epithelial cells between the follicular and luteal phase groups. Similarly, the previous studies have shown that the expression of E-cadherin and catenin in the endometrium did not change during the selected phase of oestrous (Caballero et al. 2014; Tienthai 2018) or menstrual cycle (Tabibzadeh et al. 1995; Tsuchiya et al. 2006; Carico et al. 2010). However, studies in the uterus of humans (Fujimoto et al. 1996; Shih et al., 2004) and animals (MacCalman et al. 1994; Payan-Careira et al. 2016) reported that both E2 and P4 were able to induce E-cadherin transcription.

E-cadherin and P-cadherin are major contributors to cell-cell adhesion in epithelial tissues, playing pivotal roles in maintaining integrity and homeostasis in adult tissues (Paredes et al. 2012). Furthermore, cadherins participate in the regulation of cellular homeostatic events that encompass proliferation, differentiation, and apoptosis (reviewed in Yulis et al. 2018). The cytoplasmic domain of E-cadherin and P-cadherin links to the cytoskeleton through interactions with $\beta$-catenin. It is now generally accepted that alterations in the expression and subcellular localization of these molecules are important in the development and progression of most cervical carcinomas (Li et al. 2016). In the present study, we determined that in the cow cervix, P-cadherin exhibited cytoplasmic and membranous expression patterns in the ciliated cells, and lateral membrane localization in the non-ciliated cells during the follicular and luteal phases. This finding is in contrast with previous studies showing that P-cadherin was absent in the normal columnar epithelium of the human cervix (de Boer et al. 1999; Han et al. 2000). Ecadherin and beta-catenin showed strong membranous and weak cytoplasmic expression patterns in the ciliated cells, and moderate membranous localization in the non-ciliated cells of the cow cervix throughout the oestrous cycle. This basic finding is consistent with research that have reported $\mathrm{E}$ cadherin (Vessey et al. 1995; de Boer et al. 1999; Ryan et al. 2001; Fadare et al. 2005; Blaskewicz et al. 2011; Auvinen et al. 2013) and beta-catenin (Fadare et al. 2005) expression in the lateral membrane of normal columnar epithelial cells lining the cervix, but not on the apical and basal cellular surfaces of these cells. However, this contradicts previous reports indicating no detectable intracellular E-cadherin and beta-catenin (de Boer et al. 1999; Fadere et al. 2005). The presence of P- and E-cadherin and betacatenin in the cervical epithelium of cycling cows could confirm the concept that these adhesion proteins involved in maintaining the epithelial integrity (Paredes et al. 2012) and regulation of cellular proliferation, differentiation, and apoptosis in the cervical epithelium throughout the oestrous cycle.

Previous studies demonstrated that in the squamous epithelium of the human ectocervix and vagina, Ecadherin and beta-catenin are predominantly found along the cell-to-cell borders in the basal and 
parabasal cell layers (Inoue et al. 1992; Vessey et al. 1995; Carico et al. 2001; Shinohara et al. 2001; Fadare et al. 2005; Blaskewicz et al. 2011; Auvinen et al. 2013; Zhang et al. 2014; Jiang et al. 2019; Donmez 2020) and P-cadherin is confined to the basal cell layer (Li et al. 2016). Immunohistochemical findings in the present study indicate, in contrast to what occurs in human ectocervix and vagina (Inoue et al. 1992; Vessey et al. 1995; Carico et al. 2001; Shinohara et al. 2001; Fadare et al. 2005; Blaskewicz et al. 2011; Auvinen et al. 2013; Zhang et al. 2014; Crasta et al. 2016; Li et al. 2016; Jiang et al. 2019; Donmez 2020), that in the cow vagina, $P$ and E-cadherin and beta-catenin were localized to all of the cell layers of the stratified epithelium during the oestrous cycle. The reason for this difference may be that the vaginal epithelium of the cow is different from the vaginal epithelium of most animals. In human and most species, the superficial layers of the vaginal epithelium consist of dead squamous cells that have undergone a terminal cell differentiation program called cornification, which occurs under the influence of estrogen (Anderson et al. 2014). As a consequence, terminally differentiated superficial cells do not have robust intercellular junctions (Anderson et al. 2014). In contrast, the luminal surface epithelium of the cow vagina is composed of mucus-secreting columnar cells during the oestrous cycle (Miroud and Noakes 1991). This finding is evidence that the epithelial localization patterns of P- and E-cadherin and betacatenin are species-specific.

The results of current study indicate that the cellular localization patterns of these adhesion proteins varied with the structural changes that occur in the vaginal epithelium during the oestrous cycle. During the follicular phase, the luminal surface columnar cells of the vaginal epithelium displayed strong membranous and weak cytoplasmic staining for P- and E-cadherins and beta-catenin. However, during the luteal phase, the luminal surface squamous cells of the vaginal epithelium showed moderate cytoplasmic, sometimes membranous, expression of P-cadherin, and strong membranous and moderate cytoplasmic immunostaining for E-cadherin and beta-catenin. Furthermore, the vaginal epithelial cells also exhibited nuclear immunostaining for P-cadherin throughout the oestrous cycle. Fadare et al. (2005) demonstrated that in the normal human ectocervix, E-cadherin and beta-catenin decorated the epithelium in a circumferentially membranous fashion, and no cytoplasmic or nuclear staining was present. However, Zhang et al. (2014) and Donmez (2020) showed that, in the human ectocervix and, normal epithelial cells displayed membranous and cytoplasmic beta-catenin expression in the basal and suprabasal layers, similar to the case in the cow vagina.

Beta-catenin is an essential molecule both in cadherin-mediated cell adhesion and in canonical Wnt signalling, which controls embryonic development and homeostatic self-renewal in a number of adult tissues (Clevers 2006). $\beta$-catenin exhibit three different localization patterns: membranous, cytoplasmic, and nuclear. Freshly synthesized $\beta$-catenin interacts with E-cadherin and serves as a structural protein localized to the cell membrane (Kumar and Bashyam 2017). Nuclear localized beta catenin is an indicator of activated Wnt signaling and the development or progression of cancer (Shinohara et al. 2001; RodríguezSastre et al. 2005; Zhang et al. 2014). Continuous activation of Wnt signaling encourages the uncontrolled self-renewal of cancer cells and promotes tumour metastasis and invasion (Nelson and Nusse 2004; Uren et al. 2005). Chen et al. (2014) have shown that Wnt signaling and cadherin-mediated cell adhesion interact closely with each other. Cadherins can inhibit Wnt signaling by sequestering $\beta$ - 
catenin at the membrane, thereby preventing it from entering the nucleus to transmit Wnt signals. This molecular mechanism helps maintain low levels of beta-catenin in the cytoplasm and nucleus in the absence of Wnt stimulation. In contrast, after Wnt stimulations, the transcription rates of N-cadherin increase, while the transcription rates of E-cadherin decrease (Chen et al. 2014). The cytoplasmic betacatenin expression observed in the cow cervical and vaginal epithelial cells should not be considered abnormal, as this molecule is involved in the transduction of cytosolic signals to the nucleus in a variety of cellular pathways, other than maintaining the integrity of cadherin-bearing cell-cell junctions (Du et al. 2014; McCrea et al. 2015). Furthermore, the present study revealed that nuclear beta-catenin expression was absent in the cervical and vaginal epithelium. In light of the above-mentioned reports (Nelson and Nusse 2004; Uren et al. 2005; Chen et al. 2014; Zhang et al. 2014) and considering that E-cadherin has the potent ability to recruit beta-catenin to the cell membrane and to prevent its nuclear localization (Orsulic et al. 1999), although this study is limited to immunohistochemistry, the findings corroborate that $\mathrm{E}$ - and P-cadherin may be cooperated to keep beta-catenin in the cell membrane of the cervical and vaginal epithelial cells. This may be necessary for maintaining normal epithelial morphology of the cow cervix and vagina during the oestrous cycle regulated by E2 and P4.

The immunohistochemical findings also showed that while the epithelia of the cervix and vagina did not express $\mathrm{N}$-cadherin, the positive control tissues (bovine ovary and liver) displayed positive immunostaining for $\mathrm{N}$-cadherin. $\mathrm{N}$-cadherin-positive immunostaining in the bovine ovary is similar to $\mathrm{N}$ cadherin expression reported in the rat and human ovaries (Machell et al. 2000; Tsuchiya et al. 2006). Even though these findings concur with the results of Li et al. (2016) and Vornhagen et al. (2018), Jiang et al. (2019) demonstrated that the expression level of N-cadherin was very low in normal human cervical tissues. These differences indicate that the expression of junctional adhesion molecules is species- and tissue-specific.

Previous studies have demonstrated that the E-cadherin/catenin complex plays an important role in maintaining the normal phenotype of epithelial cells, and E-cadherin is an important determinant of tumour progression, serving as a suppressor of invasion and metastasis (reviewed in Jeanes et al. 2008; Tian et al. 2011, Jiang et al. 2019). N-cadherin and E-cadherin exhibit opposite effects, where E-cadherin mediates the adhesion between epithelial cells (van Roy and Berx 2008), as indicated above, and Ncadherin promotes cell movement (Hazan et al. 2004). N-cadherin is a mesenchymal cadherin which is upregulated by epithelial cells during malignant cell transformation and epithelial-mesenchymal transition concomitantly with the loss of E-cadherin. Islam et al. (1996) demonstrated that high expression of $\mathrm{N}$-cadherin and low expression of E-cadherin are typical of squamous cell carcinomas and suggested that the inappropriate expression of $\mathrm{N}$-cadherin could result in tumorigenesis in squamous epithelial cells. Similarly, Jiang et al. (2019) have demonstrated that the expression of the epithelial indicators Ecadherin and $\beta$ catenin gradually declined, and the mesenchymal indicators Ncadherin increased with progression of the cervical lesions, and suggested that downregulation of E-cadherin and $\beta$-catenin serves a role in the occurrence and development of squamous cervical cancer. Based on previous reports (Islam et al. 1996; Orsulic et al. 1999; Jeanes et al. 2008; Jiang et al. 2019) and the present results, the absence of $\mathrm{N}$-cadherin expression, and strong membranous $\mathrm{E}$-cadherin and $\beta$-catenin 
expression may be suggested to strengthened intercellular adhesion, prevent the formation of abnormal cells during the morphological changes that occur in the cervical and vaginal epithelium throughout the cow oestrus cycle, and impede tumorigenesis.

Early studies have reported that cervical stromal cells do not exhibit any staining for E-, P- and N-cadherin (Ryan et al. 2001; Fadare et al. 2005; Li et al. 2016) and beta-catenin (Fadare et al. 2005). Thus, we are not surprised to see no immunostaining for E-cadherin and beta-catenin the cervical and vaginal stroma during the oestrous cycle. However, we observed a nuclear and cytoplasmic immunostaining patterns with anti-P-cadherin antibody in the cervical and vaginal stroma.

To the best of our knowledge, no detailed information is available on the expression of cadherins and beta-catenin in the smooth muscle cells of the cervix and vagina of humans and other mammals. However, Taylor et al. (1996) demonstrated that while the human myometrium expressed numerous cadherins in a cell-specific manner, differing among smooth muscle cells, stromal cells, and endothelial cells, the expression of cadherins in the myometrium remained constant throughout the menstrual cycle. While Khan-Dawood et al. (1997) detected E-cadherin and its mRNA in both normal myometrium and leiomyoma, Tai et al. (2003) reported the absence of E-cadherin in the normal myometrium and in uterine leiomyomas, similar expression of P-cadherin in these two tissues, and significantly higher expression of $\mathrm{N}$-cadherin and its mRNA in uterine leiomyomas, compared to the normal myometrium. Furthermore, these researchers (Tai et al. 2003) reported no difference in catenin expression between the normal myometrium and uterine leiomyomas. Our immunohistochemical findings corroborate the strong nuclear and moderate cytoplasmic P-cadherin expression in the smooth muscle cells of the bovine cervix and vagina, which remained constant throughout the oestrous cycle. It is known that many functions of smooth muscle cells such as adhesion, migration, proliferation, contraction, differentiation, and apoptosis are regulated by a broad spectrum of cell-cell and cell-matrix adhesion molecules (Frismantiene et al. 2018). Since the results of this study were limited to immunohistochemistry, we could not determine the function of P-cadherin in the smooth muscle cells in the cervix and vagina. Further studies are required to clarify this issue.

Limited data are available on the presence and localization of the cadherins and beta-catenin in the blood vessels of mammalian reproductive organs. As reported in the human endometrium (Tabibzadeh et al. 1995), in the cow cervix and vagina, N-cadherin was not observed in the vascular endothelial and smooth muscle cells. Unlike results for the endothelial cells of the human endometrium (Tabibzadeh et al. 1995), P-cadherin staining was localized to the cytoplasm and nuclei of the vascular endothelial and smooth muscle cells. In addition, similar to what was reported by Tabibzadeh et al. (1995), the immunohistochemical findings in the present study of the cow cervix and vagina indicate that betacatenin was located at the junctions between the vascular endothelial cells. This finding corroborates that P-cadherin and beta-catenin are essential to endothelial cells in terms of normal vascular patterning in the bovine cervix and vagina as reported by previous studies (George and Beeching 2006; Clifford et al. 2008). 
In conclusion, this study shows that, classical E- and P-cadherins and beta-catenin exhibit the cell-, tissue-, and organ-specific expression patterns in the cervix and vagina of cycling cows, but N-cadherin is not expressed. These results suggest that $\mathrm{E}$ - and $\mathrm{P}$-cadherins and beta-catenin participate in maintaining the normal architecture, epithelial integrity and barrier function in the cow cervix and vagina during the oestrous cycle as reported in the other mammalian reproductive organs (for a review, see Rowlands et al. 2000; Poncelet et al. 2002; Shih et al. 2004; van der Bijl and van Eyk 2004; Blaskewicz et al. 2011; Tienthai 2018). In the present study, we could not determine whether the changes in the mRNA and protein expression of cadherins and beta-catenin were due to E2 and P4 hormone levels during the oestrous cycle. However, the immunohistochemical results of the study showed that while the immunostaining intensities of $\mathrm{P}$ - and E-cadherin and beta-catenin in the cervical and vaginal components did not change during the oestrous cycle, the immunolocalization patterns in the cervical and vaginal epithelia altered with structural changes that occurred in response to E2 and P4 levels during the oestrous cycle. Given the importance of cadherins and beta catenin in cell-cell and cell-matrix adhesion, and any impairment in the expression of these molecules, is related to tumor progression, our descriptive and interpretative study demonstrating the normal expression of these basic molecular regulators of cervical and vaginal tissues may be establish baseline data for future studies of reproductive biology.

\section{Declarations}

\section{Funding}

This research did not receive any specific grant from any funding agency in the public, commercial, or not-for-profit sector.

\section{CRediT authorship contribution statement}

Narin Liman planned the study, performed the analysis of the results, and interpreted the data. In addition, she prepared the original draft and wrote the manuscript. Hakan Sağsöz performed the animal experiments, provided immunohistochemical reagents, and participate in the analysis of the results.

\section{Data availability}

The datasets in this study are available from the corresponding author on reasonable request.

\section{Compliance with ethical standards}

\section{Conflict of interest}

All authors note no conflicts of interest relevant to this study.

\section{Ethical approval}

All applicable international, national, and/or institutional guidelines for the care and use of animals were followed. 


\section{Consent to participate}

All authors participated voluntarily in the research.

\section{Consent for publication}

All authors read and approved the final manuscript.

\section{References}

1. Allan G, Campen C, Hodgen $G$ et al (2003) Identification of genes with differential regulation in primate endometrium during the proliferative and secretory phases of the cycle. Endocr Res 29:53https://doi: 10.1081/erc-120018676

2. Anderson DJ, Marathe J, Pudney J (2014) The structure of the human vaginal stratum corneum and its role in immune defense. Am J Reprod Immunol 71:618-623. https// doi: 10.1111/aji.12230

3. Arbyn M, Weiderpass E, Bruni L, de Sanjosé S, Saraiya M, Ferlay J, Bray F (2020) Estimates of incidence and mortality of cervical cancer in 2018: a worldwide analysis. Lancet Glob Health 8:e191-e203. https:// doi: 1016/S2214-109X(19)30482-6

4. Auvinen E, Capen O, Korpela T, Ronty M, Vaheri A, Tarkkanen J (2013) Altered expression of ezrin, Ecadherin and $\beta$-catenin in cervical neoplasia. Neoplasma 60:56- https://doi: 10.4149/neo_2013_008

5. Benbia S, Yahia M, Letron IR, Benounne $O$ (2017) Endometrial cells morphology depending on estrous cycle and histologic layers in cows: morphometric study. Glob Vet 18:68-73. https:// doi: 10.5829/idosi.gv.2017.68.73

6. Blaskewicz CD, Pudney J, Anderson DJ (2011) Structure and function of intercellular junctions in human cervical and vaginal mucosal epithelia. Biol Reprod 85:97- https://doi:

10.1095/biolreprod.110.090423

7. Breeveld-Dwarkasing VNA (2002) The bovine cervix explored: the cow as a model for studies on functional changes in the uterine cervix. Ph.D. Thesis, Utrecht University.

8. Caballero JN, Gervasi MG, Veiga MF et al (2014) Epithelial cadherin is present in bovine oviduct epithelial cells and gametes, and is involved in fertilization-related events. Theriogenology 81:11891206. https://doi: 10.1016/j.theriogenology.2014.01.028

9. Carico E, Atlante M, Bucci B, Nofroni I, Vecchione A (2001) E-cadherin and alpha-catenin expression during tumor progression of cervical carcinoma. Gynecol Oncol 80:156-161. https://doi: $10.1006 /$ gyno.2000.6035

10. Carico E, Atlante M, Giarnieri E, Raffa S, Bucci B, Giovagnoli MR, Vecchione A (2010) E-Cadherin and alpha-catenin expression in normal, hyperplastic and neoplastic endometrium. Anticancer Res 30:4993-4997.

11. Chen GTC, Getsios S, MacCalman CD (1998) Progesterone regulates $\beta$-catenin mRNA levels in human endometrial stromal cells in vitro. Endocrine 9:263-267. 
12. Chen J, Xie Z-R, Wu Y (2014) Computational modeling of the interplay between cadherin-mediated cell adhesion and Wnt signaling pathway. PLoS ONE 9: e100702.

https://doi.org/10.1371/journal.pone.0100702

13. Clevers $H$ (2006) Wnt/beta-catenin signaling in development and disease. Cell 127:469-4 https://doi: 10.1016/j.cell.2006.10.018

14. Clifford RL, Deacon K, Knox AJ: Novel regulation of vascular endothelial growth factor-A (VEGF-A) by transforming growth factor (beta)1: Requirement for SMADs, beta-catenin, and GSK3(beta). J Biol Chem 283(51): 35337-35353, 2008. https://doi: 10.1074/jbc.M803342200

15. Crasta J, Ravikumar G, Koorse S, Siddharta P, Vallikad E (2016)Expression of adhesion molecule epithelial cadherin and matrix metalloproteinase-9 in squamous neoplasia of the uterine cervix. South Afr J Gynaecol Oncol 8:4- https://doi: 10.1080/20742835.2015.1110419

16. Crossmon $G$ (1937) A modification of Mallory's connective tissue stain with a discussion of the principles involved. Anat Rec 69:33-38

17. Crowe MA (2011) Reproduction, events and management: Estrous cycles: Characteristics. In: Fukuay JW (ed) Encyclopedia of Dairy Sciences (Second edition). Academic Press, San Diego, pp 428-433.

18. Dadarwal D, Palmer C, Griebel Philip (2017) Mucosal immunity of the postpartum bovine genital tract. Theriogenology 104:62-71. https://doi: 10.1016/j.theriogenology.2017.08.010.

19. de Boer $C J$, van Dorst $E$, van Krieken $\mathrm{H}$ et al (1999) Changing roles of cadherins and catenins during progression of squamous intraepithelial lesions in the uterine cervix. Am J Pathol 155:505https://doi: 10.1016/S0002-9440(10)65146-2.

20. De Tomasi BJ, Opata MM, Mowa CN (2019) Immunity in the cervix: Interphase between immune and cervical epithelial cells. J Immunol Res 2019:1-13. https://doi: 10.1155/2019/7693183

21. Detre S, Jotti G, Dowsett M (1995) A quickscore method for immunohistochemical semiquantitation: Validation for oestrogen receptor in breast carcinomas. J Clin Path 48: 876-878. https://doi: 10.1136/jcp.48.9.876

22. Donmez HG (2020) $\beta$-Catenin immunocytochemical reactivity in cervicovaginal smears during regular menstrual cycles. Asian Biomed (Res Rev News) 14:187-194. https://doi.org/10.1515/abm2020-0027

23. Doorbar J, Griffin H (2019) Refining our understanding of cervical neoplasia and its cellular origins. Papillomavirus Res 7:176- https://doi: 10.1016/j.pvr.2019.04.005

24. Du W, Liu X, Fan G et al (2014) From cell membrane to the nucleus: an emerging role of E-cadherin in gene transcriptional regulation. J Cell Mol Med 18:1712- https://doi: 10.1016/j.pvr.2019.04.005

25. Fadare O, Reddy H, Wang J, Hileeto D, Schwartz PE, Zheng W (2005) E-cadherin and beta-catenin expression in early stage cervical carcinoma: a tissue microarray study of 147 cases. World J Surg Oncol 3:38. https://doi: 1186/1477-7819-3-38

26. Fay PC, Cook CG, Wijesiriwardana N, Tore G, Comtet L, Carpentier A, Shih B, Freimanis G, Haga IR, Beard PM (2020) Madin-Darby bovine kidney (MDBK) cells are a suitable cell line for the propagation 
and study of the bovine poxvirus lumpy skin disease virus. J Virol Methods 285:113943- https://doi: 10.1016/j.jviromet.2020.113943

27. Felix JC, Lonky NM, Tamura K et al (2002) Aberrant expression of E-cadherin in cervical intraepithelial neoplasia correlates with a false-negative Papanicolaou smear. Am J Obstet Gynecol 186:1308- https://doi: 10.1067/mob.2002.123732.

28. Frismantiene A, Philippova M, Erne P, Resink TJ (2018) Cadherins in vascular smooth muscle cell (patho)biology: Quid nos scimus? Cell Signal 45:23-42. https://doi: 10.1016/j.cellsig.2018.01.023

29. Fujimoto J, Ichigo S, Hori M, Tamaya T (1996) Alteration of E-cadherin, alpha- and beta-catenin mRNA expression in human uterine endometrium during the menstrual cycle. Gynecol Endocrinol 10:187- https://doi: 10.3109/09513599609027987

30. George SJ, Beeching CA (2006) Cadherin:catenin complex: a novel regulator of vascular smooth muscle cell behaviour. Atherosclerosis 188:1-11. https://doi: 10.1016/j.atherosclerosis.2005.12.017

31. Gumbiner BM (2005) Regulation of cadherin-mediated adhesion in morphogenesis. Nat Rev Mol Cell Biol 6:622- https://doi: 10.1038/nrm1699

32. Guo B, Han B-C, Tian Z et al (2010) Expression and hormonal regulation of E-cadherin in canine uterus during early pregnancy. Reprod Domest Anim 45:e255-e259. https://doi: 10.1111/j.14390531.2009.01550.x

33. Halbleib JM, Nelson WJ (2006) Cadherins in development: cell adhesion, sorting, and tissue morphogenesis. Genes Dev Genes Dev 20:3199-3214. https://doi: 10.1101/gad.1486806

34. Han AC, Edelson MI, Peralta Soler A et al (2000) Cadherin expression in glandular tumors of the cervix. Cancer 89:2053-2058. https://doi: 10.1002/1097-0142(20001115)89:10<2053::aidcncr4>3.0.co;2-c

35. Harris TJ, Tepass U (2010) Adherens junctions: from molecules to morphogenesis. Nat Rev Mol Cell Biol11:502-514. https://doi: 10.1038/nrm2927

36. Hazan RB, Qiao R, Keren R, Badano I, Suyama K (2004) Cadherin switch in tumor progression. Ann N Y Acad Sci 1014:155-163. https://doi: 10.1196/annals.1294.016

37. Huber AH, Weis WI (2001) The structure of the $\beta$-catenin/ E-cadherin complex and the molecular basis of diverse ligand recognition by $\beta$-catenin. Cell 105:391-402. https://doi: 10.1016/s00928674(01)00330-0

38. Inoue M, Ogawa $H$, Miyata M, Shiozaki $H$, Tanzawa $O$ (1992) Expression of E-cadherin in normal, benign, and malignant tissues of female genital organs. Am J Clin Pathol 98:76- https://doi: 10.1093/ajcp/98.1.76

39. Islam S, Carey TE, Wolf GT, Wheelock MJ, Johnson KR (1996) Expression of N-cadherin by human squamous carcinoma cells induces a scattered fibroblastic phenotype with disrupted cell-cell adhesion. J Cell Biol 135:1643- https://doi: 10.1083/jcb.135.6.1643

40. Jeanes A, Gottardi C, Yap A (2008) Cadherins and cancer: how does cadherin dysfunction promote tumor progression? Oncogene27:6920-6929. https://doi: 10.1038/onc.2008.343 
41. Jeong JW, Lee HS, Franco HL et al (2009) Beta-catenin mediates glandular formation and dysregulation of beta-catenin induces hyperplasia formation in the murine uterus. Oncogene 28:3140. https://doi:10.1038/onc.2008.363

42. Jiang J, Li X, Yin X, Zhang J, Shi B (2019) Association of low expression of E-cadherin and $\beta$-catenin with the progression of early stage human squamous cervical cancer. Oncol Lett 17:5729https://doi: 10.3892/ol.2019.10266

43. Jha RK, Titus S, Saxena D, Kumar PG, Laloraya M (2006) Profiling of E-cadherin, beta-catenin and $\mathrm{Ca}(2+)$ in embryo-uterine interactions at implantation. FEBS Lett 580:5653-5660. https://doi: 10.1016/j.febslet.2006.09.014

44. Khan-Dawood FS, Lee K-H, Dawood MY (1997) E-cadherin protein and its m-RNA are present in normal myometrium and leiomyoma. Fertil Steril 68:S71-S72. https:// doi: 10.1002/mrd.10248

45. Kiewisz J, Kaczmarek MM, Andronowska A, Blitek A, Ziecik AJ (2011) Gene expression of WNTs, $\beta$ catenin and E-cadherin during the periimplantation period of pregnancy in pigs involvement of steroid hormones. Theriogenology 76:687-699. https://doi: 10.1016/j.theriogenology.2011.03.022

46. Kumar R, Bashyam MD (2017) Multiple oncogenic roles of nuclear beta-catenin. J Biosci. 2017 42:695- doi: 10.1007/s12038-017-9710-9

47. Larsen B, Hwang J (2011) Progesterone interactions with the cervix: translational implications for term and preterm birth. Infect Dis Obstet Gynecol 2011:1-13. https://doi: 10.1155/2011/353297

48. Lee S-H, Jung BD, Lee S (2019) Effect of prostaglandin F2 alpha on E-cadherin, N-cadherin and cell adhesion in ovarian luteal theca cells. Korean J Clin LabSci 51:360https://doi.org/10.15324/kjcls.2019.51.3.360

49. Li J, Zhang JV, Cao Y-J et al (2005) Inhibition of the beta-catenin signaling pathway in blastocyst and uterus during the window of implantation in mice. Biol Reprod 72:700-706. https://doi: 10.1095/biolreprod.104.033837

50. Li B, Shi H, Wang F et al (2016) Expression of E-, P- and N-cadherin and its clinical significance in cervical squamous cell carcinoma and precancerous lesions. PloS One 11:e0155910. https://doi: 10.1371/journal.pone.0155910

51. Luan L, Ding T, Stinnett A, Reese J, Paria BC (2011) Adherens junction proteins in the hamster uterus: their contributions to the success of implantation. Biol Reprod 85:996-1004. https://doi: 10.1095/biolreprod.110.090126

52. MacCalman CD, Farookhi R, Blaschuk OW (1994) Estradiol and progesterone regulate E-cadherin mRNA levels in the mouse uterus. Endocrine 2:485-490. https://doi: 10.1007/BF01753834

53. Machell NH, Blaschuk OW, Farookhi R (2000) Developmental expression and distribution of N- and Ecadherin in the rat ovary. Biol Reprod 63:797-804. https://doi: 10.1095/biolreprod63.3.797

54. McCrea PD, Maher MT, Gottardi CJ (2015) Nuclear signaling from cadherin adhesion complexes. Curr Top Dev Biol 112:129-196. https://doi: 10.1016/bs.ctdb.2014.11.018

55. Millward S, Mueller K, Smith R, Higgins HM (2019) A post-mortem survey of bovine female reproductive tracts in the UK. Front Vet Sci. 2019 6:451. https://doi: 10.3389/fvets.2019.00451 
56. Miroud K, Noakes DE (1991) Histological changes in the vaginal mucosa of the cow during the oestrous cycle, after ovariectomy and following exogenous oestradiol benzoate and progesterone treatment. Br Vet J 147:469-477. https://doi: 10.1016/0007-1935(91)90090-A

57. Mohamed OA, Jonnaert M, Labelle-Dumais JC, Kuroda K, Clarke HJ, Dufort D (2005) Uterine Wnt/ßcatenin signaling is required for implantation. PNAS 102:8579-8584. https://doi:

10.1073/pnas.0500612102

58. Mullins KJ, Saacke R (1989) Study of the functional anatomy of bovine cervical mucosa with special reference to mucus secretion and sperm transport. Anat Rec 225:108-117. https://doi: 10.1002/ar.1092250205

59. Nelson WJ (2008) Regulation of cell-cell adhesion by the cadherin-catenin complex. Biochem Soc Trans 36:149-155. https://doi: 10.1042/BST0360149

60. Nelson WJ, Nusse R (2004) Convergence of Wnt, $\beta$-catenin, and cadherin pathways. Science 303:1483-1487. https://doi: 10.1126/science.1094291

61. Nollet F, Kools P, van Roy F (2000) Phylogenetic analysis of the cadherin superfamily allows identification of six major subfamilies besides several solitary members. J Mol Biol 299:551https://doi: 10.1006/jmbi.2000.3777

62. Orsulic S, Huber O, Aberle H, Arnold S, Kemler R (1999) E-cadherin binding prevents beta-catenin nuclear localization and beta-catenin/LEF-1-mediated transactivation. J Cell Sci 112:1237-1245.

63. Paredes J, Figueiredo J, Albergaria A et al. (2012) Epithelial E- and P-cadherins: role and clinical significance in cancer. Biochim Biophys Acta1826:297-311. https://doi:

10.1016/j.bbcan.2012.05.002

64. Payan-Carreira R, Pires MA, Santos C, Holst BS, Colaço J, Rodriguez-Martinez H (2016) Immunolocalization of E-cadherin and $\beta$-catenin in the cyclic and early pregnant canine endometrium. Theriogenology 86:1092-1101. https://doi: 10.1016/j.theriogenology.2016.03.041

65. Peralta OA, Pearson RE, Nebel RL (2005) Comparison of three estrus detection systems during summer in a large commercial dairy herd. Anim Reprod Sci 87:59-72. https://doi:

10.1016/j.anireprosci.2004.10.003

66. Pessina MA, Hoyt RF, Golstei I, Traish AM (2006) Differential effects of estradiol, progesterone, and testosterone on vaginal structural integrity. Endocrinology 147:61-69. https://doi: 10.1210/en.20050870

67. Poncelet C, Leblanc M, Walker-Combrouze F et al (2002) Expression of cadherins and CD44 isoforms in human endometrium and peritoneal endometriosis. Acta Obstet Gynecol Scand 81:195-203. https://doi: 10.1034/j.1600-0412.2002.810302.x

68. Potter SW, Gaza G, Morris JE (1996) Estradiol induces E-cadherin degradation in mouse uterine epithelium during the estrous cycle and early pregnancy. J Cell Physiol 169:1-14. https://doi: 10.1002/(SICI)1097-4652(199610)169:1<1::AID-JCP1>3.0.C0;2-S

69. Rider V, Isuzugawa K, Twarog M et al (2006) Progesterone initiates Wnt-beta-catenin signaling but estradiol is required for nuclear activation and synchronous proliferation of rat uterine stromal cells. 
J Endocrinol 191:537-548. https://doi: 10.1677/joe.1.07030

70. Rizvi AA, Quraishi MI, Sarkar V, DuBois C, Biro S, Mulhall J (2009) The effect of pH and viscosity on bovine spermatozoa motility under controlled conditions. Int Urol Nephrol 41:523-530. https://doi: 10.1007/s11255-008-9493-x

71. Rodríguez-Sastre M, González-Maya L, Delgado R, Mohar A, García-Carrancá A (2005) Abnormal distribution of E-cadherin and $\beta$-catenin in different histologic types of cancer of the uterine cervix. Gynecol Oncol 97:330-336. https://doi: 10.1016/j.ygyno.2004.12.062

72. Rowlands TM, Symonds M, Farookhi R and Blaschuk OW (2000) Cadherins: crucial regulators of structure and function in reproductive tissues. Rev Reprod 5:53-61. https://doi:

$10.1530 /$ ror. 0.0050053

73. Ryan PL, Baum DL, Lenhart JA, Ohleth KM, Bagnell CA (2001) Expression of uterine and cervical epithelial cadherin during relaxin-induced growth in pigs. Reproduction 122:929-937.

74. Sheldon IM, Cronin JG, Healey GD et al (2014) Innate immunity and inflammation of the bovine female reproductive tract in health and disease. Reproduction 148:R41- https://doi: 10.1530/REP14-0163

75. Shih HC, Shiozawa T, Miyamoto T et al (2004) Immunohistochemical expression of E-cadherin and $\beta$-catenin in the normal and malignant human endometrium: an inverse correlation between $\mathrm{E}$ cadherin and nuclear $\beta$-catenin expression. Anticancer Res 24:3843-

76. Shinohara A, Yokoyama Y, Wan X et al (2001) Cytoplasmic/nuclear expression without mutation of exon 3 of the beta-catenin gene is frequent in the development of the neoplasm of the uterine cervix. Gynecol Oncol 82:450-455. https://doi: 10.1006/gyno.2001.6298

77. Tabibzadeh S, Babaknia A, Kong QFet al (1995) Menstruation is associated with disordered expression of desmoplakin I/II and cadherin/catenins and conversion of F- to G-actin in endometrial epithelium. Hum Reprod 10:776-784. https://doi:10.1093/oxfordjournals.humrep.a136037

78. Tai CT, Lin WC, Chang WC, Chiu TH, Chen GT (2003) Classical cadherin and catenin expression in normal myometrial tissues and uterine leiomyomas. Mol Reprod Dev 64:172-178. https://doi: 10.1002/mrd.10248

79. Taylor CV, Letarte M, Lye SJ (1996) The expression of integrins and cadherins in normal human uterus and uterine leiomyomas. Am J Obstet Gynecol 175:411-419. https://doi: 10.1016/s00029378(96)70155-2

80. Tian X, Liu Z, Niu B et al (2011)E-cadherin/beta-catenin complex and the epithelial barrier. J Biomed Biotechnol 2011:567305. https://doi: 10.1155/2011/567305

81. Tienthai P (2018) E-cadherin localization in oviduct and uterine horn of swamp buffalo during estrous cycle. Thai J Vet Med 48: 357-

82. Tsiligianni T, Amiridis GS, Dovolou E et al. (2011) Association between physical properties of cervical mucus and ovulation rate in superovulated cows. Can J Vet Res 75:248-253.

83. Tulac S, Nayak NR, Kao LC et al (2003) Identification, characterization, and regulation of the canonical Wnt signaling pathway in human endometrium. J Clin Endocrinol Metab 88:3860-3866. 
https://doi: 10.1210/jc.2003-030494

84. Tsuchiya B, Sato Y, Kameya T, Okayasu I, Mukai K (2006) Differential expression of N-cadherin and Ecadherin in normal human tissues. Arch Histol Cytol 69:135- https://doi: 10.1679/aohc.69.135

85. Uren A, Fallen S, Yuan $\mathrm{H}$ et al (2005) Activation of the canonical Wnt pathway during genital keratinocyte transformation: a model for cervical cancer progression. Cancer Res 65:6199-6206. https://doi: 10.1158/0008-5472.CAN-05-0455

86. van der Horst PH, Wang Y, van der Zee M, Burger CW, Blok LJ (2012) Interaction between sex hormones and WNT/beta-catenin signal transduction in endometrial physiology and disease. Mol Cell Endocrinol 358:176- https://doi: 10.1016/j.mce.2011.06.010

87. van der Linden PJ, de Goeiji AF, Dunselman GA, Arends JW, Evers JL (1994) P-cadherin expression in human endometrium and endometriosis. Gynecol Obstet Invest 38:183-185. https://doi: $1159 / 000292475$

88. van der Linden PJ, de Goeji FPM, Dunselman GAJ, Erkens HWH, Ewers JHL (1995) Expression of cadherins and integrins in human endometrium throughout the menstrual cycle. Fertil Steril 63:1210-1216. https://doi: 10.1016/s0015-0282(16)57599-2

89. van Roy F, Berx G (2008) The cell-cell adhesion molecule E-cadherin. Cell Mol Life Sci. 2008 Nov;65(23):3756-3788. https://doi: 10.1007/s00018-008-8281-1

90. Vessey C, Wilding J, Folarin $\mathrm{N}$ et al (1995) Altered expression and function of E-cadherin in cervical intraepithelial neoplasia and invasive squamous cell carcinoma. J Pathol 176:151-159. https://doi: 10.1002/path.1711760208

91. Vornhagen J, Armistead B, Santana-Ufret V et al (2018) Group B streptococcus exploits vaginal epithelial exfoliation for ascending infection. J Clin Invest 128:1985-1999. https://doi:

$10.1172 / J C I 97043$

92. Wrobel KH, Laun G, Hees H, Zwack M (1986) Histologic and ultrastructural studies of the vaginal epithelium of the cow. Anat Histol Embryol 15:303-328. https://doi:10.1111/j.14390264.1986.tb00543.x

93. Wrobel KH (1971) Histologische, histochemische und elektronenmikroskopische untersuchungen an der cervix uteri des rindes. Habilitationsschrift, Beiheft zum Zbl Vet. Med 15, Verlag Paul Parey, Berlin.

94. Yue Z, GuoB, Zhang Q, Zhang X, Li Z (2009) Expression and hormonal regulation of E-cadherin in canine uterus during early pregnancy. Biol Reprod 81:296. https://doi.org/10.1093/biolreprod/81.s1.296

95. Yulis M, Kusters DHM, Nusrat A (2018) Cadherins: cellular adhesive molecules serving as signalling mediators. J Physiol 596:3883-3898. https://doi: 10.1113/JP275328

96. Zhang Y, Liu B, Zhao Q, Hou T, Huang X (2014) Nuclear localization of $\beta$-catenin is associated with poor survival and chemo-/radioresistance in human cervical squamous cell cancer. Int $J$ Clin Exp Pathol 7:3908-3917.

\section{Tables}


Table 1. Localization and immunostaining intensity of $\mathrm{P}-, \mathrm{E}-$, and $\mathrm{N}$ - cadherins and $\beta$-catenin in the layers of the bovine cervix and vagina during the estrous cycle. Immunostainings in the cervical and vaginal tissues were semi-quantitatively evaluated using an intensity score that reflected the intensity of positive staining in the cell membrane, cytoplasm and nucleus. Intensity score was recorded as (-) or negative (no staining even at high magnification, X40), (+) or weak (only visible at high magnification, $\mathrm{X} 40),(++)$ or moderate (readily visible at low magnification, X10), and (+++) or strong (strikingly positive at low power magnification, $\mathrm{X} 10$ ). Subcellular localization of staining: c, cytoplasmic staining; $m$, membrane staining; $\mathrm{n}$, nuclear staining; ve, staining of endothelial cells; vsmc, staining of smooth muscle cells in blood vessels. 


\begin{tabular}{|c|c|c|c|c|c|c|}
\hline \multirow{2}{*}{$\begin{array}{l}\text { AJ } \\
\text { proteins }\end{array}$} & \multirow{2}{*}{$\begin{array}{l}\text { Lower } \\
\text { genital tract } \\
\text { organs }\end{array}$} & \multirow{2}{*}{$\begin{array}{l}\text { The estrous } \\
\text { cycle phase }\end{array}$} & \multicolumn{4}{|l|}{ Tissue layers } \\
\hline & & & Epithelium & $\begin{array}{l}\text { Stromal } \\
\text { cells }\end{array}$ & $\begin{array}{l}\text { Smooth } \\
\text { muscle } \\
\text { cells }\end{array}$ & $\begin{array}{l}\text { Blood } \\
\text { vessels }\end{array}$ \\
\hline \multirow[t]{9}{*}{$\begin{array}{l}\text { P- } \\
\text { cadherin }\end{array}$} & \multirow[t]{4}{*}{ Cervix } & \multirow[t]{2}{*}{ Follicular } & $\begin{array}{l}\text { Ciliated cells: } \mathrm{c} \\
\mathrm{m} /+++\end{array}$ & \multirow[t]{2}{*}{$\mathrm{c}, \mathrm{n} /++$} & $\begin{array}{l}\mathrm{c} /++ \\
\mathrm{n} /+++\end{array}$ & \multirow{2}{*}{$\begin{array}{l}\text { ve: } \\
\text { c/++, } \\
\text { n/+++ } \\
\text { vsmc: } \\
\text { c/++, } \\
\text { n/+++ }\end{array}$} \\
\hline & & & $\begin{array}{l}\text { Non-ciliated cells: } \\
\mathrm{m} /+++\end{array}$ & & & \\
\hline & & \multirow[t]{2}{*}{ Luteal } & $\begin{array}{l}\text { Ciliated cells: c, } \\
\mathrm{m} /+++\end{array}$ & \multirow[t]{2}{*}{$c, n /++$} & $\begin{array}{l}\mathrm{c} /++ \\
\mathrm{n} /+++\end{array}$ & \multirow{2}{*}{$\begin{array}{l}\text { ve: } \\
\text { c/++, } \\
\text { n/+++ } \\
\text { vsmc: } \\
\text { c/++, } \\
\text { n/+++ }\end{array}$} \\
\hline & & & $\begin{array}{l}\text { Non-ciliated cells: } \\
\mathrm{m} /+++\end{array}$ & & & \\
\hline & \multirow[t]{5}{*}{ Vagina } & \multirow[t]{3}{*}{ Follicular } & Basal cells: $\mathrm{c}, \mathrm{m} /++$ & \multirow[t]{3}{*}{$c, n /++$} & $\begin{array}{l}\mathrm{c} /++ \\
\mathrm{n} /++\end{array}$ & \multirow{3}{*}{$\begin{array}{l}\text { ve: } \\
\text { c/++, } \\
\text { n/+++ } \\
\text { vsmc: } \\
\text { c/++, } \\
\text { n/+++ }\end{array}$} \\
\hline & & & $\begin{array}{l}\text { Parabasal cells: } \mathrm{c}, \\
\mathrm{m} /++\end{array}$ & & & \\
\hline & & & $\begin{array}{l}\text { Columnar superficial } \\
\text { cells: } \mathrm{m} /+++, \mathrm{c} /++\end{array}$ & & & \\
\hline & & \multirow[t]{2}{*}{ Luteal } & $\begin{array}{l}\text { Basal cells: c, m /++ } \\
\text { Parabasal cells: c, m } \\
\text { /++ }\end{array}$ & \multirow[t]{2}{*}{$\mathrm{c}, \mathrm{n} /++$} & \multirow[t]{2}{*}{$\begin{array}{l}\mathrm{c} /++ \\
\mathrm{n} /++\end{array}$} & \multirow{2}{*}{$\begin{array}{l}\text { ve: } \\
\text { C/++, } \\
\text { n/+++ } \\
\text { vsmc: } \\
\text { C/++, } \\
\text { n/+++ }\end{array}$} \\
\hline & & & $\begin{array}{l}\text { Squamous } \\
\text { superficial cells: c } \\
/++\end{array}$ & & & \\
\hline \multirow{8}{*}{$\begin{array}{l}\text { E- } \\
\text { cadherin }\end{array}$} & \multirow[t]{4}{*}{ Cervix } & \multirow[t]{2}{*}{ Follicular } & Ciliated cells: $\mathrm{m} /+++$ & \multirow[t]{2}{*}{-} & \multirow[t]{2}{*}{-} & ve: - \\
\hline & & & $\begin{array}{l}\text { Non-ciliated cells: } \\
\mathrm{m} /+++\end{array}$ & & & vsm: - \\
\hline & & \multirow[t]{2}{*}{ Luteal } & Ciliated cells: $\mathrm{m} /+++$ & \multirow[t]{2}{*}{-} & \multirow[t]{2}{*}{-} & ve: - \\
\hline & & & $\begin{array}{l}\text { Non-ciliated cells: } \\
\mathrm{m} /+++\end{array}$ & & & vsmc: - \\
\hline & \multirow[t]{4}{*}{ Vagina } & \multirow[t]{3}{*}{ Follicular } & $\begin{array}{l}\text { Basal cells: } \mathrm{m} /+++ \\
\mathrm{c} /++\end{array}$ & \multirow[t]{3}{*}{-} & \multirow[t]{3}{*}{-} & \multirow{3}{*}{$\begin{array}{l}\text { ve: - } \\
\text { vsmc: - }\end{array}$} \\
\hline & & & $\begin{array}{l}\text { Parabasal cells: } \\
\mathrm{m} /+++, \mathrm{c} /++\end{array}$ & & & \\
\hline & & & $\begin{array}{l}\text { Columnar superficial } \\
\text { cells: } \mathrm{m} /+++, \mathrm{c} /++\end{array}$ & & & \\
\hline & & Luteal & Basal cells: m/+++, & - & - & ve: - \\
\hline
\end{tabular}


Parabasal cells:

$\mathrm{m} /+++, \mathrm{c} /++$

Squamous

superficial cells:

$\mathrm{m} /+++, \mathrm{c} /++$

\begin{tabular}{|c|c|c|c|c|c|c|}
\hline \multirow{4}{*}{$\begin{array}{l}\mathrm{N} \text { - } \\
\text { cadherin }\end{array}$} & \multirow[t]{2}{*}{ Cervix } & Follicular & - & - & - & - \\
\hline & & Luteal & - & - & - & - \\
\hline & \multirow[t]{2}{*}{ Vagina } & Follicular & - & - & - & - \\
\hline & & Luteal & - & - & - & - \\
\hline \multirow[t]{10}{*}{$\begin{array}{l}\beta- \\
\text { catenin }\end{array}$} & \multirow[t]{4}{*}{ Cervix } & Follicular & $\begin{array}{l}\text { Ciliated cells: } \mathrm{m} /+++ \\
\mathrm{c} /++\end{array}$ & - & - & $\begin{array}{l}\text { ve: } \\
\mathrm{m} /+++\end{array}$ \\
\hline & & & $\begin{array}{l}\text { Non-ciliated cells: } \\
\mathrm{m} /+++\end{array}$ & & & vsmc: - \\
\hline & & Luteal & $\begin{array}{l}\text { Ciliated cells: } \mathrm{m} /+++ \\
\mathrm{c} /++\end{array}$ & - & - & $\begin{array}{l}\text { ve: } \\
\mathrm{m} /+++\end{array}$ \\
\hline & & & $\begin{array}{l}\text { Non-ciliated cells: } \\
\mathrm{m} /+++\end{array}$ & & & vsmc: - \\
\hline & \multirow[t]{6}{*}{ Vagina } & Follicular & $\begin{array}{l}\text { Basal cells: } \mathrm{m} /+++ \\
\mathrm{c} /+\end{array}$ & - & - & $\begin{array}{l}\text { ve: } \\
\mathrm{m} /+++\end{array}$ \\
\hline & & & $\begin{array}{l}\text { Parabasal cells: } \\
\mathrm{m} /+++, \mathrm{c} /+\end{array}$ & & & vsmc: - \\
\hline & & & $\begin{array}{l}\text { Columnar superficial } \\
\text { cells: } \mathrm{m} /+++, \mathrm{c} /+\end{array}$ & & & \\
\hline & & Luteal & $\begin{array}{l}\text { Basal cells: } \mathrm{m} /+++ \\
\mathrm{c} /+\end{array}$ & - & - & $\begin{array}{l}\text { ve: } \\
\mathrm{m} /+++\end{array}$ \\
\hline & & & $\begin{array}{l}\text { Parabasal cells: } \\
\mathrm{m} /+++, \mathrm{c} /+\end{array}$ & & & vsmc: - \\
\hline & & & $\begin{array}{l}\text { Squamous } \\
\text { superficial cells: } \\
\mathrm{m} /+++, \mathrm{c} /+\end{array}$ & & & \\
\hline
\end{tabular}

Figures 

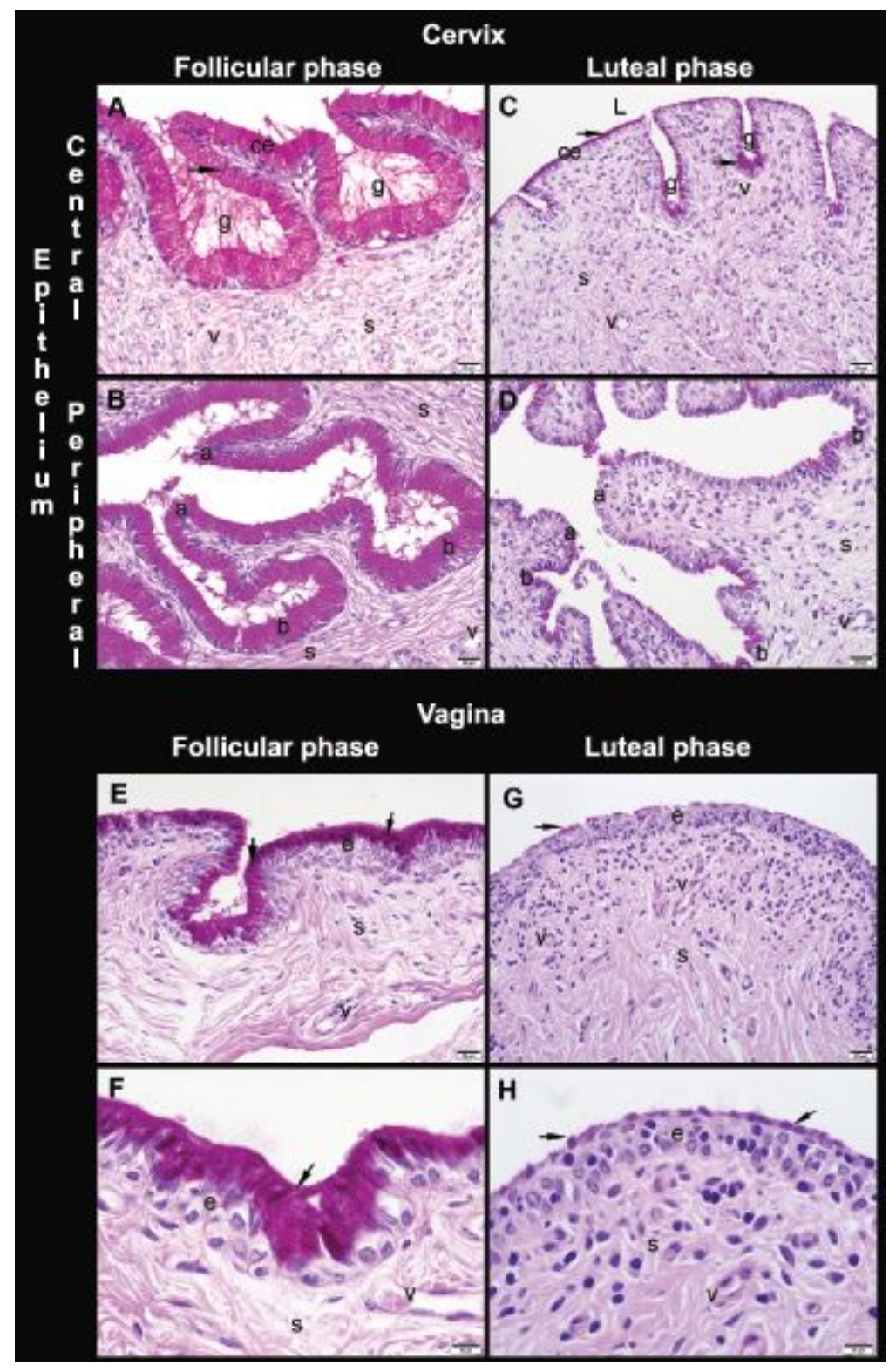

Figure 1

The mucosa of the cow cervix and vagina during the follicular and luteal phases of the oestrous cycle. In the cervix, during the follicular phase, non-ciliated columnar cells contained a large amount of stored PAS-positive mucins in the apical cytoplasm (A and B), whereas, during the luteal phase, the amount of PAS-positive mucins stored in the non-ciliated epithelial cells was greatly reduced ( $C$ and $D)$. In the vagina, during the follicular phase, the most superficial cells of the epithelium were columnar cells containing a large amount of stored PAS-positive mucins (E and F), whereas during the luteal phase, the superficial cells of the epithelium were squamous or cuboidal cells containing small amounts of stored PAS-positive mucins ( $G$ and $H$ ). a, apical area of the peripheral region; $b$, basal area of the peripheral region; ce, central epithelium of the cervix, e, vaginal epithelium; $g$, grooves in the central and peripheral regions of the cervix; L, lumen; s, stroma; v, blood vessel; arrows, PAS-positive mucins in the vaginal epithelium. Periodic acid-Schiff (PAS) stain. Scale bars: $20 \mu \mathrm{m}(\mathrm{A}-\mathrm{E}, \mathrm{G}), 10 \mu \mathrm{m}(\mathrm{F}, \mathrm{H})$. 


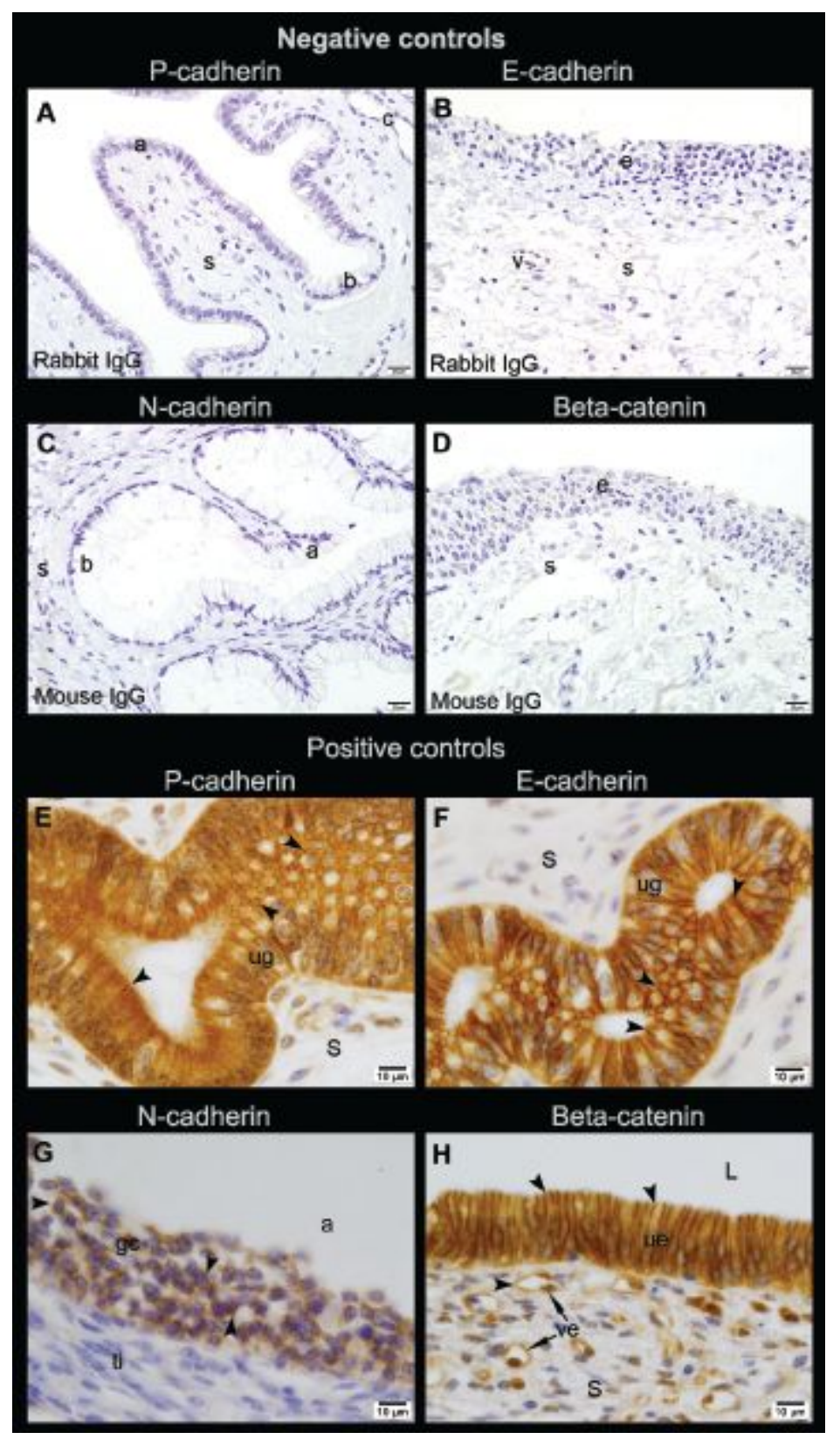

Figure 2

The immunostainings in the negative and positive control tissues. Negative controls, produced using rabbit or mouse IgG, resulted in no immunostaining for all antibodies in the bovine cervix $(A, C)$ and vagina $(B, D)$. P-cadherin $(E)$, E-cadherin $(F)$, and beta-catenin $(H)$ immunostaining localized to the epithelium lining the lumen (ue) and endometrial glands (ug) of the bovine uterus. N-cadherin-positive immunostaining was localized to the granulosa cells (gc) within the Graaf follicles in the bovine ovary $(G)$; b, basal area of the epithelium lining the grooves; ce, central epithelium of the cervix, e, vaginal epithelium; g, grooves; L, lumen; s, stroma; v, blood vessel. Scale bars: A-D, $20 \mu \mathrm{m} ; \mathrm{E}-\mathrm{H}, 10 \mu \mathrm{m}$ 


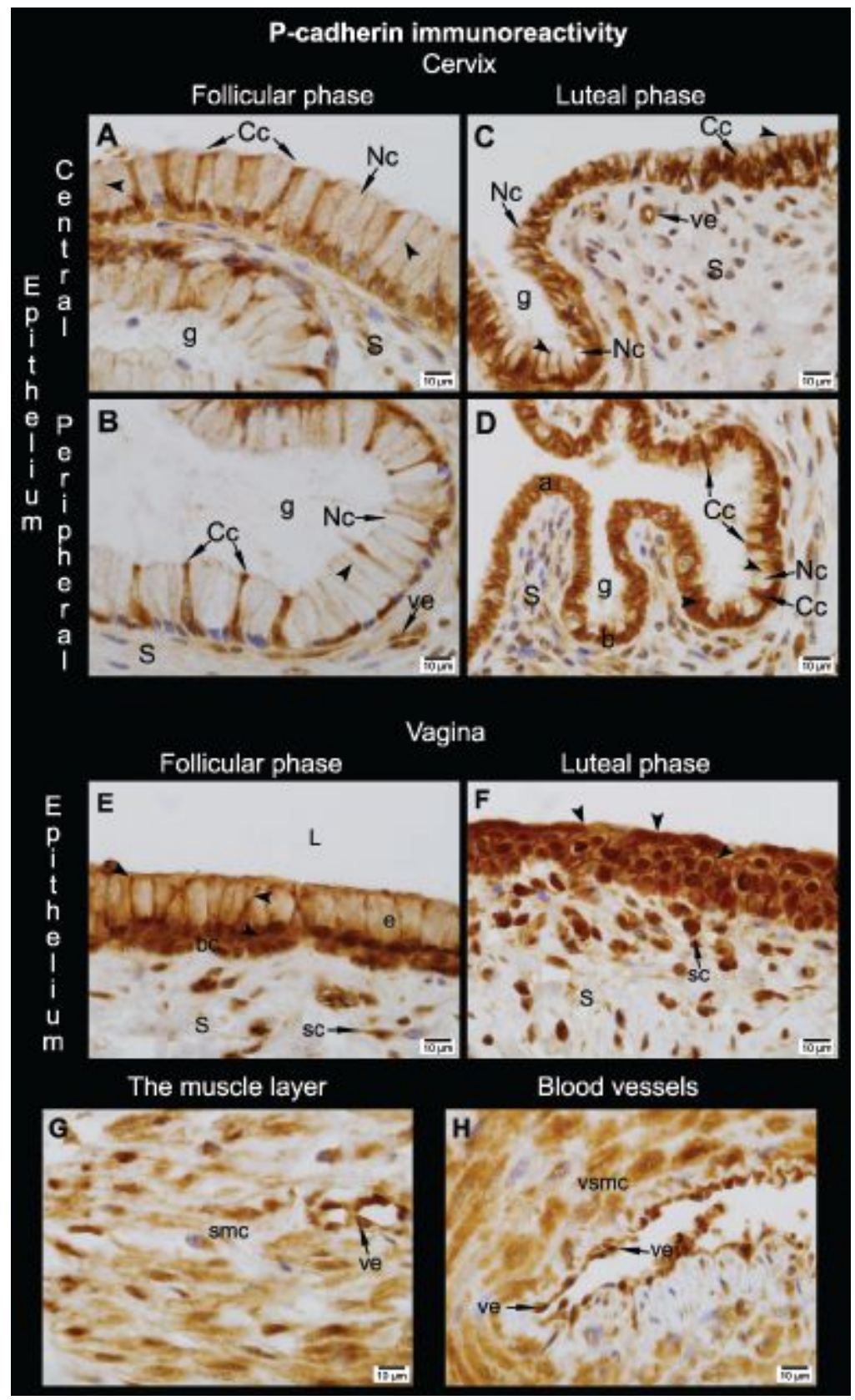

Figure 3

P-cadherin immunoreactivity in the cow cervix and vagina during the follicular and luteal phases of the oestrous cycle; immunohistochemical stain, diaminobenzidine as the chromogen. In the cervix, Pcadherin (A-D) displayed membrane staining (arrow heads) in the ciliated (Cc) and non-ciliated cells (Nc) of the central and peripheral region epithelium. Throughout the oestrous cycle, the basal and intermediate cell layers of the vaginal epithelium (e) showed nuclear, cytoplasmic, and membranous (arrow heads) staining for P-cadherin (E, F). During the follicular phase, the mucus-secreting superficial cells displayed membranous and cytoplasmic staining for $P-(E)$, while during the luteal phase, the superficial squamous cells showed membranous, cytoplasmic and nuclear immunostaining patterns for P-cadherin (F). Pcadherin immunoreactivity was observed in the nuclei and cytoplasm of many stromal cells (sc), smooth 
muscle cells (smc) (G), and vascular endothelial (ve) and smooth muscle cells (vsmc) (H). bc, basal cells; g, grooves in the central and peripheral regions of the cervix; L, lumen; S, stroma. Scale bars: $10 \mu \mathrm{m}$.

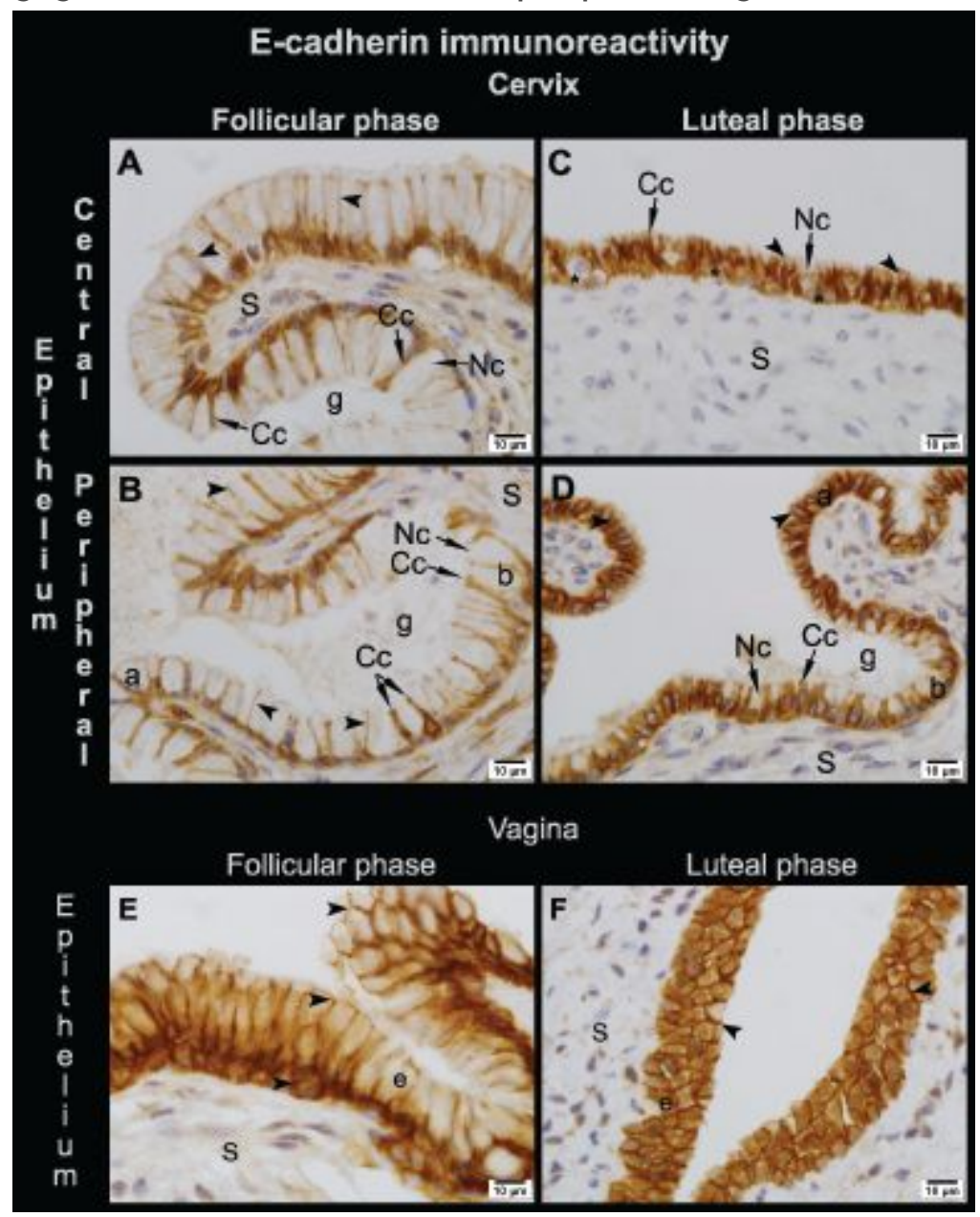

Figure 4

E-cadherin immunoreactivity in the cow cervix and vagina during the follicular and luteal phases of the oestrous cycle; immunohistochemical stain, diaminobenzidine as the chromogen. In the central and peripheral region epithelium of the cervix, E-cadherin (A-D) exhibited membrane staining (arrow heads) in the ciliated (cc) and non-ciliated cells (Nc). Throughout the oestrous cycle, the basal and intermediate cell layers of the vaginal epithelium (e) showed cytoplasmic and membranous staining (arrow heads) for Ecadherin $(E, F)$. During the follicular phase, the mucus-secreting superficial cells displayed membranous and cytoplasmic staining for E-cadherin (E), while during the luteal phase, the superficial squamous cells showed membranous and cytoplasmic immunostaining for E-cadherin (F). g, grooves in the central and peripheral regions of the cervix; S, stroma. Scale bars: $10 \mu \mathrm{m}$. 

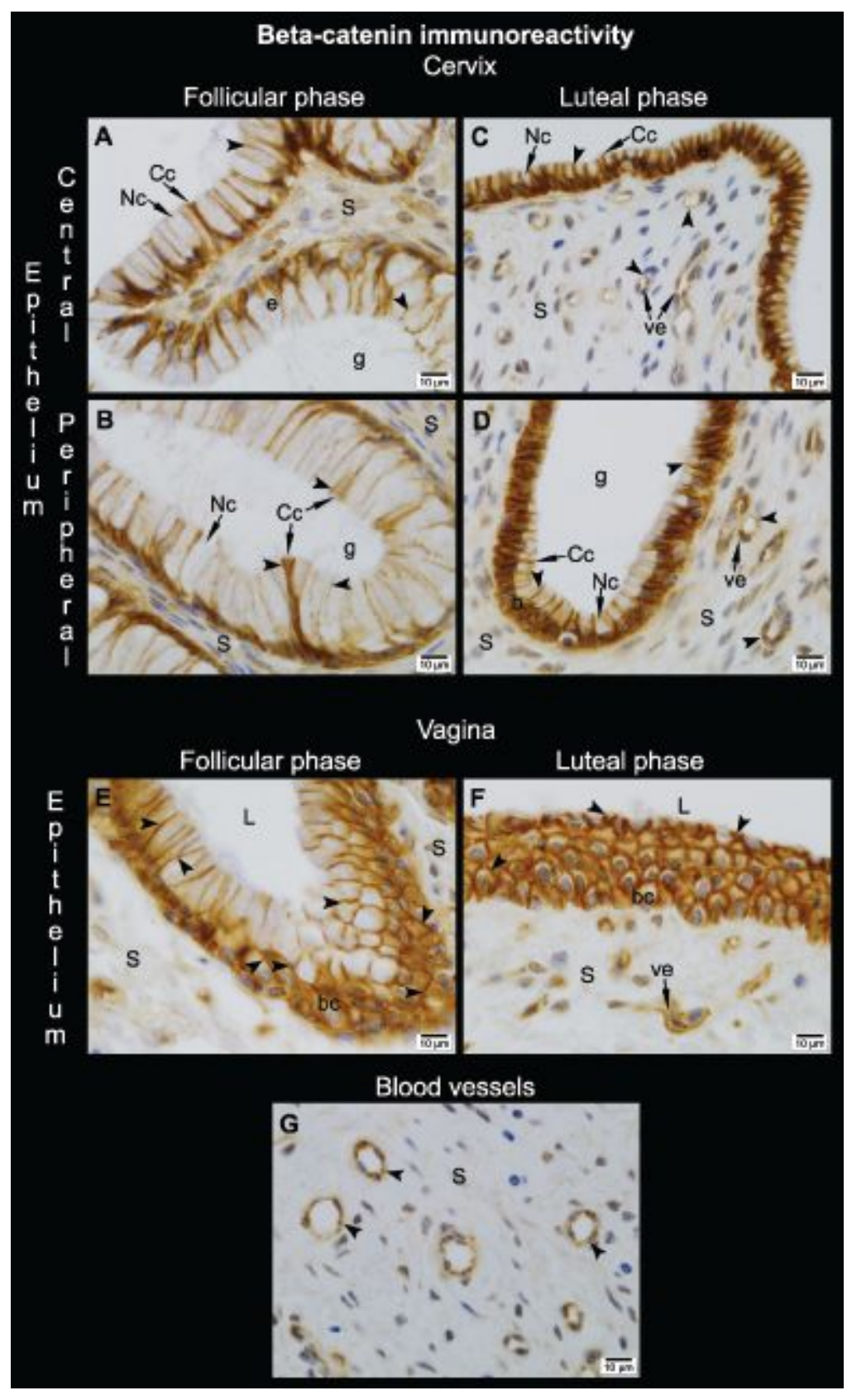

Figure 5

Beta-catenin immunoreactivity in the cow cervix and vagina during the follicular and luteal phases of the oestrous cycle; immunohistochemical stain, diaminobenzidine as the chromogen. In the cervix, betacatenin (A-D) exhibited membrane staining (arrowheads) in the ciliated (cc) and non-ciliated cells (Nc) of the central and peripheral region epithelium of the cervix. Throughout the oestrous cycle, in the vagina, the basal (bc) and intermediate cell layers of the vaginal epithelium showed cytoplasmic and membranous staining (arrow heads) for beta-catenin ( $E, F)$. The membranous (arrowheads) and cytoplasmic staining for beta-catenin was observed in both the mucus-secreting superficial cells $(\mathrm{E})$ and the squamous superficial cells $(F)$ of the vaginal epithelium, which were found during the follicular and luteal phase, respectively. Beta-catenin immunoreactivity was also detected in the lateral plasma membrane (arrowheads) of the endothelial cells (ve) of both the cervical and vaginal blood vessels (C, D, 
F, and G). g, grooves in the central and peripheral regions of the cervix; L, lumen; S, stroma. Scale bars: 10 $\mu \mathrm{m}$ 